\title{
François Noël (1651-1729) and his Latin translations of Confucian Classical books published in Prague in 1711
}

\author{
Vladimír Liščák \\ Department of East Asia, Oriental Institute, Academy of Sciences, Pod Vodárenskou věží 4, 18208 Praha 8
}

Received $15^{\text {th }}$ November 2014; accepted $20^{\text {th }}$ February 2015

\section{FRANÇOIS NOËL (1651-1729) A JEHO LATINSKÉ PŘEKLADY KONFUCIÁNSKÝCH KLASICKÝCH KNIH VYDANÉ V PRAZE V ROCE 1711}

\begin{abstract}
ABSTRAKT První setkání Evropy s konfucianismem se připisuje jesuitům, kteří působili v Číně v 16. až 18. století. Na počátku byl překlad úvodu k Da xue 大學 do latiny, publikovaný v Ř́mě roku 1593. Nicméně, první překlad konfuciánských klasických knih, jenž přitáhl značnou pozornost, byl Confucius Sinarum Philosophus, publikovaný v Paříži v roce 1687. Tato publikace obsahovala komentovaný překlad tří ze Čty r knih konfuciánského kánonu. Nový překlad uvedených knih byl vydán v Praze v roce 1711. Jeho autorem byl François Noël (1651-1729), belgický (vlámský) básník, dramatik a jezuita v Číně. Jeho Sinensis Imperii Libri Classici Sex obsahovaly nový překlad prvních tří z již dříve přeložených Čtyř knih a byl doplněn o Mencia (Mengzi 孟子). V této své knize rovněž zahrnul i Klasickou knihu synovské úcty (Xiao jing 孝經), jednu z třinácti klasických knih, a Malé či Základní učení (Xiao Xue 小學), sbírku textů pro děti pořízenou Zhu Xim 朱喜. Překlady jsou rozděleny do malých, číslovaných oddílů, stejně jako čínský originál. Pokud jsou uvedeny poznámky, často na konci úseku, jsou obvykle doprovázeny jménem komentátora. Noëlova práce se jeví jako důležitý pokus o vědeckou prezentaci starověkého textu, snad v záměrném kontrastu k cílům jesuitů, kteří sestavili knihu Confucius Sinarum Philosophus o půl století dříve.
\end{abstract}

KLÍČOVÁ SLOVA François Noël; latinské překlady; Philosophia Sinica; Sinensis Imperii Libri Classici Sex; Historica notitia rituum

ABSTRACT The first acquaintance of Europe with Confucianism is contributed to Jesuits working in China in the $16^{\text {th }}$ to $18^{\text {th }}$ centuries. At the beginning was the translation of introduction to Da xue 大學 into Latin, published in Rome (Italy) in 1593. However, the first translation of the Confucian classic books, which attracted significant attention, was Confucius Sinarum Philosophus (Confucius, the Chinese philosopher), published in Paris in 1687. This publication has contained the annotated translation of three of Four Books of the Confucian canon. It is important, that new translation of the mentioned books was published in Prague in 1711. The author was François Noël (1651-1729), a Belgian (Flemish) poet, dramatist and Jesuit in China. His Sinensis Imperii Libri Classici Sex (Six Classics of Chinese Empire) has contained a new translation of the first three of the Four Books and added the Mencius (Mengzi 孟子). He also included in this book the Classic of Filial Piety (Xiao jing 孝經), one of the Thirteen Classics, as well as the Small Learning (Xiao xue 小學), a collection of texts put together for children by Zhu Xi 朱喜. The translations are divided up in small, numbered sections like the Chinese original. Noël's work appears to be a serious attempt at a scholarly presentation of the ancient text, perhaps in deliberate contrast to the aims of the Jesuits who composed their Confucius Sinarum Philosophus half a century before.

KEY WORDS François Noël; Latin translations; Philosophia Sinica; Sinensis Imperii Libri Classici Sex; Historica notitia rituum

\section{INTRODUCTION}

The first acquaintance of Europe with Confucianism is contributed to Jesuits working in China in the 16th to 18 th centuries. At the beginning was the translation of the introduction to Da xue 《大學》 [Great Learning] into Latin, published in Rome (Italy) in 1593 (Michele Ruggieri). ${ }^{1}$ In 1662, the first

1 Translation of several lines of the $D a$ Xue in: Antonii Possevini Societatis Iesv Bibliotheca selecta qua agitur de ratione stvdiorum in historia, in disciplinis, in salute omnium procuranda. T. I. Romæ: Ex Typographia Apostolica Vaticana, M. D. XCIII. (1593), lib. IX, p. 583. 
Latin translation of some parts of the Confucian canon was published in China by Inácio da Costa (1603-1666) and Prospero Intorcetta (1626-1696). However, the first translation of the Confucian classic books, which attracted significant attention, was Confucius Sinarum philosophus [Confucius, the Chinese philosopher], published in Paris in 1687. This publication has contained the annotated translation of three of Four Books 《四書》 of the Confucian canon.

The translations of the Confucian canon are closely connected with the missionary activities of the Jesuits (Societas Iesu). The history of the Jesuits in China can be viewed as having been bounded by either of two different sets of dates:

1. from Francis Xavier's (1506-1552) arrival in 1552 to the disbanding of the Jesuits in $1773^{2}$, or

2. from Matteo Ricci's (1552-1610) reception in 1600 at the Chinese court to the death of the last Jesuit in Peking (Father de Poirot $)^{3}$ in 1813.

In addition to setting up missionary activities among the people as had the Franciscans, the Jesuits also set about exploring classical Chinese thought. The Jesuits' main reason for studying the Chinese canonical works was to aid in their missionary activities. As a result, most of the Jesuits used and interpreted the Confucian classics as their catechetical supplements to Christian doctrines. (Dai 1981, p. 256)

Francis Xavier, one of the ten founding fathers of the Jesuits, visited India and Japan. While preaching in Japan, he learned that China was the centre of Asian civilization. He then left Japan for China, but died on the island of Shangchuan (Ilha Sanchoão, St. John's Island, 上川島 Shàngchuān Dǎo), off the coast of China. Although he never reached mainland China, he is still honoured as the father of the China mission, as well as the father of Jesuit missions in general. As the pioneer of Jesuit missionary activities, his policies became the models for Jesuit missionary work. His approach was radical at the time, based on the philosophy that Christianity must be expressed in the native languages using concepts derived from the indigenous culture. He felt that missionaries could not proselytize effectively unless they were equipped with proper training in local language and philosophy.

Alessandro Valignano (1539-1606; Chinese name: 范禮安 Fàn $L \grave{l}{ }^{\prime} \bar{a} n$ ), the second major Jesuit in the East Asian mission, successfully opened the China mission. In order to avoid Portuguese domination (based on padroado), he chose fellow Italian Jesuits, Michele Ruggieri (1543-1607; Chinese name: 羅明堅 Luó Míngjiān), Francesco Pasio (1551-1612), and

2 Pope Clement XIV disbanded the Jesuits in 1773 through an encyclical entitled Dominus et Redemptor.

3 Louis Antoine de Poirot (1735-1813; Chinese name: 賀清泰 Hè Qingtài) was a Jesuit painter and translator of the 18th and early 19th century, who worked in the service of the Chinese emperor Qianlong 乾隆. He was the last of the Western painters who worked for Qianlong, together with Father Giuseppe Panzi (1734-before 1812; Chinese name: 潘廷章 Pān Tíngzhāng). Poirot also made a translation of the Old Testament in the Manchu language, and a translation of the New Testament into the Chinese language.
Matteo Ricci, for the China mission. Like Xavier, he wanted his Italian Jesuits to learn the Chinese dialects and become adept in Chinese philosophy as well.

Following Valignano's directions, Ruggieri and Ricci garbed themselves in Buddhist habits. After they became more sensitive to the Chinese intellectuals' Confucian orientation, they adopted Confucian robes. In order to understand the Chinese, Ruggieri and Ricci both studied Confucian classics diligently. These studies would enable them to teach succeeding Jesuit missionaries the complexities of Chinese culture, and also to send accounts of Confucianism back to Europe.

Ruggieri was the first Jesuit to translate the Confucian Four Books into Latin; however, he was prohibited from publishing this work and his Chinese catechism 《天主實錄》 (Tiānzhǔ shílu) in Latin, because of the opposition of Valignano and Ricci. Ruggieri's Latin translation of the Confucian classics was only a by-product; his major concern was to make the Bible in some form available in Chinese. ${ }^{4}$

Like Ruggieri, also Ricci prepared a rough translation of the Four Books, known as the Tetrabiblion Sinense de moribus [Chinese Four Books on morals], at some time prior to November, 1593. Unfortunately, there is no trace of this work in any European archives. About its existence we known only from contemporary references in the literature. (Mungello 1989, 250-251; D'Arelli 1998) Ricci maintained that the contemporary Chinese interpretations of Confucianism were too metaphysical, that emphasis should be placed on the pragmatic aspects of Chinese ethics and political organization.

Prior to the publication of Confucius Sinarum philosophus in 1687, the Jesuit missionaries focused their efforts on formulating catechetical interpretations of Confucianism in Chinese. They studied the Confucian classics and adopted Confucian sayings in their Christian publications. In addition to Ricci's and Ruggieri's two Chinese catechisms, Ricci wrote sixteen books in Chinese. Most of the other seventeenth century Jesuit missionaries in China were also competent in Chinese composition. (Chen 1970, p. 81)

\section{THE FIRST LATIN TRANSLATION OF THE CONFUCIAN CANON}

When the Jesuits faced difficulties in preaching to the Chinese, they retreated to their work on the translation of the Confucian classics. In 1662, the first Latin translation of the Confucian canon was published in China by Inácio da Costa (1603-1666; Chinese name: 郭納爵 Guō Nàjué) and Prospero Intorcetta (1626-1696; Chinese name: 殷鐸澤 Yìn Duózé). This Latin translation only included parts of the Lun $y u$ 《論語》

[Annalects] and the Daxue 《大學》 [Great Learning], two

4 He eventually published his 《天主實錄》 [True Record of the Lord of Heaven] in 1584. (Rule 1973, p. 88) The Chinese term for God in the title of this book, 天主 (Lord of Heaven), has remained the name for God in China and also the Chinese name used for the Catholic religion. 
of the Confucian Four Books. ${ }^{5}$ In 1667, Intorcetta published, in Guangzhou 廣州, a part of one of the other Confucian canon, Zhong yong 《中庸》 [Doctrine of the Mean], under the title of Sinarum Scientia Politico-Moralis. ${ }^{6}$ In 1669, an edition of this latter work was published in Goa, to which was appended a preface and a "Life of Confucius" (Confucii vita). ${ }^{7}$ After Intorcetta returned to Europe in 1668, his books were reprinted in Paris in $1672^{8}$ and translated into French in 1676. The rarity of the works in European libraries demonstrates their limited circulation.

\section{CONFUCIUS SINARUM PHILOSOPHUS ${ }^{9}$}

It was only with the publication of Confucius Sinarum philosophus in 1687 that European scholars began noticing these works on China. This book represented the cumulative, collaborative result of the Jesuit interpretations of Chinese culture. In particular, it included translations of three of the Confucian canons: Tá-Hiŏ, Magna Scientia [Great Learning, 大學], Chùm-yâm, Medium sempiternum [Doctrine of the Mean, 中庸] and Lún Yú, Ratiocinantium Sermones [Analects, 論語]. Since Ricci rejected Mencian interpretations of Confucian classics, the Mencius 《孟子》 was not included. ${ }^{10}$ Ricci also excluded all of the commentaries by later Chinese scholars, which Chinese traditionally study along with the original texts.

The European interpretations of the Confucian classics in the Confucius Sinarum philosophus touched off the Chinese Rites Controversy in Europe. This controversy grew out of Ricci's policy that the Chinese should be allowed to continue to perform public and private Confucian rites. Some Jesuits, among them his successor Nicholas Longobardi (Nicolò Longobardo, 1559-1654, or 1565-1655; Chinese name: 龍華民 Lóng Huámín), opposed Ricci's liberal policies. This controversy

5 Sapientia Sinica exponente P. Ignatio a Costa Lusitano Soc. Ies. à P. Prospero Intorcetta Siculo eiusd. soc. orbi proposita. Kiam-cham in urbe Sinarum Provinciæ Kiam-si, 1662.

6 Sinarvm Scientia Politico-Moralis a P. Prospero Intorcetta Sicvlo Societatis Iesv, in lucem edita. Quam-Cheu (= Canton), 1667.

7 Sinarvm Scientia Politico-Moralis a P. Prospero Intorcetta Sicvlo Societatis Iesv, in lucem edita. Goæ, 1669.

8 Paris edition: Sinarvm scientia politico-moralis, sive Scientice Sinica liber inter Confvcii libros secvndvs, a P. Prospero Intorcetta ... in latinam versa ... Parisiis, 1672.

9 Confucius Sinarum philosophus, sive Scientia Sinensis latine exposita: studio et opera Prosperi Intorcetta, Christiani Herdtrich, Francisci Rougemont, Philippi Couplet, Patrum Societatis Jesu. Parisiis, Apud Danielem Horthemels, viâ Jacobæâ, sub Mæcenate, M. DC. LXXXVII. (1687)

10 Ricci criticized (in his Tianzhu shiyi 天主實義, “True Doctrine of the Lord of Heaven", Vol. II, p. 67) a saying in Mencius "There are three kinds of unfilial persons; the worst is the one who has no offspring." Since the Jesuits did not marry, they could not agree with this opinion. was further stirred by the general debates among European intellectuals resulting from the Latin translations just mentioned.

The Confucius Sinarum philosophus is a magnificently printed folio, published from the manuscript in the Royal Library by orders of Louis the Great (Louis le Grand, i.e. Louis XIV of France, 1638-1715, reign: 1643-1715). It contains translations of the first three of the Four Books and a life of Confucius ${ }^{11}$ with a full-page, icon-like portrait of the sage ${ }^{12}$. There is a very long introduction, called Proëmialis Declaratio [Methodological Introduction] ${ }^{13}$, and Couplet's Tabula Chronologica Monarchice Sinicee is added at the end of the book ${ }^{14}$.

Most of these texts must have been composed in Guangzhou between 1665 and 1671, when twenty-two Jesuits, four Dominicans and one Franciscan, expelled from their mission stations, were living together in one of the Jesuit churches in that city. It may well be that it owes its birth to the relative leisure and the somewhat unsettled atmosphere of this exile, but the history of the composition of the various parts of the work and the details of the final editing in Paris have not been elucidated. (Lundbæk 1991, p. 38)

The four authors listed on the title page of Confucius Sinarum philosophus (i.e. Prospero Intorcetta, Christian Wolfgang Herdtrich, 1624-1684; Chinese name: 恩理格 Ēn Lĭgé, François de Rougemont, 1624-1676; Chinese name: 魯日滿 Lǔ Rimăn, Philippe Couplet, 1622-1693; Chinese name: 柏應理 Băi Yìnglì) were all in their early forties and had come to China between 1658 and 1660. As mentioned above, Intorcetta had already completed his Chinese-Latin edition of the Great Learning and the first part of the Analects. He had also translated or was about to translate the Doctrine of the Mean. Rougemont may have been the main translator of the rest of the Analects, perhaps with the help of Herdtrich, but this fine calligrapher may have been busy writing the many Chinese characters that were, according to the plan, to be printed alongside the Latin text. It is not known, whether Couplet took part in the translation work perhaps being wholly absorbed in composing his Tabula Chronologica.

Intorcetta came to Rome as the procurator in 1671, bringing with him his two short works and perhaps also an introduction which came to be used - after many revisions - for the first part of the Proëmialis Declaratio. The remainder of the texts were sent after him, but he did not get to see them by the time he departed for China in March 1673. It was left to Philippe Couplet, who was in Europe between 1682 and 1693, to arrange for the edition of the work. Perhaps Couplet made

11 "Philosophorum Sinensium Principis Confucii Vita," in: Confucius Sinarum philosophus, pp. cxvii-cxxiv.

12 Ibid., p. cxvi.

13 "Proëmialis Declaratio" in: Confucius Sinarum philosophus, pp. ix-cxiv.

14 Tabula Chronologica Monarchice Sinica juxta cyclos annorum LX. Ab anno ante Christum 2952. ad annum post Christum 1683. Auctore R. P. Philippo Couplet Belgâ, Soc. Jesu, Sinensis Missionis in Urbem Procuratore. Parisiis, M. DC. LXXXVI. (1686). 
the many revisions and deletions in the texts, and wrote the last part of the Proëmialis Declaratio - he signed it as if the whole of it was his work. ${ }^{15}$

The translations are long-winded paraphrases, slightly "christianizing" in many cases the Chinese text. The Proëmialis Declaratio has two main points. Firstly, the adulation of ancient Confucian moral philosophy or natural theology, together with the denigration of the metaphysical comments appended to it by the Song philosophers, the Neo-Confucians. And secondly an apology for the special missionary technique initiated by Matteo Ricci, the so-called accommodation method, criticized by a few of the Jesuits and by most of the non-Jesuit missionaries.

The Confucius Sinarum philosophus is not a scholarly work but rather a grandiose piece of missionary propaganda, intended to promote the Jesuits' China mission.

\section{FRANÇOIS NOËL - EARLY YEARS}

New translation of the mentioned books was published in Prague in 1711. The author was François Noël (1651-1729; Latin: Franciscus Noël; Chinese name: Wei Fangji 衛方濟), a Belgian (Flemish) poet, dramatist and Jesuit in China. His Sinensis Imperii libri classici sex [Six Classics of Chinese Empire] has contained a new translation of the first three of the Four Books and added the Mencius 《孟子》. He also included in this book the Xiao jing 《孝經》 [Classic of Filial Piety], one of the Thirteen Classics 《十三經》, as well as the Xiao xue 《小學》[Small Learning], a collection of texts put together for children by Zhu Xi 朱喜. (Mungello 1983, 515-541)

The late seventeenth/early eighteenth century Jesuit, François Noël, was born on 18 August 1651 in Hestrud, in the French part of the County of Hainaut (Hainaut français), which is today within the borders of France, just on the border between France and Belgium. As he was born in the historic Flemish territory, he sometimes calls himself a "Fleming". (Rule 2003, p. 137)

Noël joined the Society of Jesus (Societas Iesu, S.J.) on 30 September 1670 in Tournai (now in Belgium), in the Jesuit Provincia Gallo-Belgica, at nineteen years of age. He made the usual education of the Jesuits. He studies theology at Douai (in Romance Flanders, Flandre romane, now in France), and also followed mathematics and astronomy. Afterwards, he became professor of Latin and Rhetoric in Tournai.

Noël's career was extraordinary in many respects. He wanted to go to the Japan mission, but this was impossible, because Japan was closed for all Europeans and especially for priests. He left Lisbon for the East in January 1684, like his fellow Belgian Jesuit and immediate predecessor, Antoine Thomas (1644-1709; Chinese name: 安多 Ān Duō), under the patronage of Maria, Duchess of Aveiro (D. Maria de Guadalupe de Lancastre Cardenas Manrique, Duquesa de Aveiro, 1630-

15 “Proëmialis Declaratio" in: Confucius Sinarum philosophus, p. cxiv.
1715). He tried to go to Japan, but in vain. Therefore he went to Macao where he arrived on 9 August 1685. In Macao he made his four solemn vows on 2 February 1686.

\section{NOËL IN CHINA}

Next to other attempts to get in Tokugawa Japan, which failed, Noël settled for the China Mission. Having done preparatory Chinese language studies in Macao, he crossed over into China proper in 1687. He continued his Chinese studies in Shanghai 上海 and began his mission work on Chongming Island 崇明島 at the beginning of October 1688. By August of the following year he was claiming spectacular success in his evangelisation of the Chongming district and Shanghai, which confirms the view of this period as a high point in Catholic conversion.

The mission activities of François Noël from 1687 to 1702 were mostly in South-central China, especially various cities in the modem Jiangxi 江西, Jiangsu 江蘇, and Anhui 安徽 provinces: Huaian 淮安, Nanking 南京, Wuhe 五河, Nanchang 南昌, Ganzhou 輯 州, Jianchang 建昌, Nanfeng 南豐, and Nan'an 南安. (Rule 2003, p. 139) However, in the beginning of 1702 he was sent as procurator for the Jesuit China Mission to Rome, together with his confrere, the Bavarian Caspar Castner (or Caspar Kastner, Kaspar Castner, 16651709; Chinese name: 龐嘉賓 Páng Jiābìn), to act in favour for the Chinese Rites.

\section{NOËL AND THE CHINESE RITES CONTROVERSY}

It is not certain why Noël, a missionary from the provinces who, so far as we know, had never been near the court, nor had much contact with Chinese scholars, was chosen as procurator, but it was probably due to the esteem in which he was held by his fellow Belgian, Antoine Thomas (1644-1709; Chinese name: 安多 $\bar{A} n(\bar{u} \bar{o})$, then the Jesuit Vice-Provincial. Thomas had left Europe for China four years before Noël and was ten years his senior in the Society of Jesus, and they seem never to have been together in China, except for ten days in Macao in August 1685. However, besides being members of the same Jesuit province, they shared a common enthusiasm for the Japanese mission and Noël had collaborated with Thomas on a project to upgrade maps of Siam, Macao and Japan. Thomas may have known Noël's early reputation in Belgium for scholarship and eloquence.

In 1704, Noël and Castner submitted in the name of their brethren and of four Chinese bishops a collection of documents to the Holy Office, which was responsible for the decision in the Rites Controversy. These documents should support the accommodation policy of the Jesuits: besides Tianzhu 天主, Lord of the Heaven, also Tian 天 (Heaven) and Shangdi 上帝 (Emperor on High) should be permitted as names for the Christian God, the Chinese Christians should be permitted to take part at the veneration of the Ancestors and of Confucius. 
In 1706 Noël left Lisbon with Castner back for China, reaching Macao on 22 July 1707. The unusual feature of this voyage was that, on the insistence of Castner, the mathematician, the captain of the ship experimented with a new quicker route which henceforth became standard: via Timor and then directly to Macao, bypassing Goa and the Straits of Malacca. (Rule 2003, p.152)

But instead of returning to his mission, less than six months later Noël was aboard ship once more en route for Europe. Already in 1708, he was sent again to Rome, this time by the emperor Kangxi 康熙帝 (1662-1721). He was in company of the two Jesuits, António Francesco Giuseppe Provana (16621720; Chinese name: 艾若瑟 Ài Ruòsè) and José Ramón Arxó (1663-1711; Chinese name: 陸失石 Lù Shìshî), and of the Chinese Jesuit Louis Fan (1682-1753; 㚞守義 Fán Shǒuyi) ${ }^{16}$. They should get a good solution of the controversy, namely that Confucianism and Christianity were compatible.

They left Macao on 14 January 1708 on the Portuguese ship Bom Jesus de Mazagão das Brotas and sailed via Batavia and Bahía in Brazil to Lisbon where they arrived in September. Provana and Fan reached Rome in February 1709 after a considerable stay in Portugal, but it is possible that Noël preceded them.

\section{FRANÇOIS NOËL IN PRAGUE}

We do not know how long he remained in Rome, but in 1711 we find him in Prague, where he published his major works. In Prague Noël began lecturing mathematics at the Jesuit-run Charles-Ferdinand University (now Charles University) in Prague. ${ }^{17}$ He used his stays in Prague to publish several books on Chinese religion, philosophy, the rites and a translation of the Sishu 《四書》, the "Four Classics", namely as the first complete translation of the Lunyu, the Zhongyong, the Daxue and the Mengzi.

Noël has also published a book on mathematical observations. A collection of astronomical observations taken in India and

16 Louis Fan Shouyi was the first Chinese to live in the West who reported about his experiences after his return to China. He arrived in Lisbon in 1708 as an aide to Francesco Provana, S.J., who was ambassador of the Kangxi emperor to the pope. Fan entered the Jesuit Order in Rome in 1708 and was ordained priest in 1717. In 1719 he returned to China with Provana. He reported on Europe in at least one audience with the emperor. The eyewitness account, Shenjianlu 身見錄, was written at the request of Kangxi, who wanted first-hand information about Europe; and Fan took the opportunity to stress the achievements of Catholic civilization. (Chatterjee 2008, p. 88)

17 On 23 February 1654 Emperor Ferdinand III (1608-1657) merged the former independent universities of Carolinum and Clementinum and created a single university with four faculties. Carolinum had at that time only the faculty of arts, as the only faculty surviving the period of the Hussite Wars. Starting at this time, the university designated itself Charles-Ferdinand University (Latin: Universitas Carolo-Ferdinandea). The dilapidated Carolinum was rebuilt in 1718 at the expense of the state.
China reveals yet another talent of this multi-faceted man. ${ }^{18}$ The three major works, however, the Chinese Philosophy, the Six Classical Books of the Chinese Empire, and the Historical Notice of the Chinese Rites and Ceremonies, are all about sinological matters and must be the fruit of his previous ten years of advocacy for the China Mission and its views. Perhaps those four years at sea had given him leisure for the task, and his work of collating and translating documents for the Roman congregations was clearly the foundation for these books about China. A draft exists for the introduction and first treatise of the Chinese Philosophy but unfortunately it bears no indication of date, and extant but incomplete manuscripts of the Six Books are dated 1700, demonstrating that the translations had been begun in China. ${ }^{19}$

\section{PHILOSOPHIA SINICA}

The Philosophia Sinica ${ }^{20}$ is a quite sophisticated work, and in many ways an advance on its Jesuit predecessors. Like them it quotes liberally from Chinese sources, but unlike many of them, does not seek to evade the problems posed by NeoConfucianism by dismissing it as a Buddhizing corruption of original Confucianism. Rather it attempts to find in NeoConfucian terminology a development of early Confucian concepts. Taiji 太極, $l i$ 理 etc. are not materialistic concepts, but "perfections" or "operations" of God, that is Tian 天 or Shangdi 上帝. They have the same relation to God as European concepts like Nature. ${ }^{21}$ Nevertheless, since their "signification is as it stands, very vague, uncertain, and indiscriminate," the Jesuit missionaries have always avoided their use for the Christian God. ${ }^{22}$ The Philosophia Sinica was, of course, conceived in the heat of the Rites Controversy, leading in Remusat's judgment to distortion, but remains a considerable work of scholarship.

18 Observationes mathematica et physica in India et China factee à Patre Francisco Noël Societatis Jesu, ab anno 1684 usque ad annum 1708. Prag $\propto$, typis Universit. Carolo-Ferdinande $e$, in Collegio Soc. Jesu ad S. Clementem, per Joachimum Joannem Kamenicky factorem, 1710. [National Library in Prague, sign. 49 B 44, 49 B 105]

19 E. g. Memcius ex sinico in latinum idioma traductus a P. Francisco Noël Societatis Iesu missionario Sinensi, Nancham in China, 1700. - Dudink, Ad C. M. Chinese Books and Documents (pre-1900) in the Royal Library of Belgium at Brussels. Brussels, Archives et Bibliothèques de Belgique, Archief- en Bibliotheekwezen in België, 2006, pp. 45-47.

20 Philosophia Sinica tribus tractatibus, Primo Cognitionem Primi Entis, Secundo Ceremonias erga Defunctos, Tertio Ethicam, Juxta Sinarum mentem complectens, Authore P. Francisco Noël Societ. Jesu missionario. Pragae, typis Universit. Carolo-Ferdinandeae, in Collegio Soc. Jesu ad S. Clementem, per Joachimum Joannem Kamenicky factorem, anno 1711. [National Library in Prague, sign. D IV 34, 49 E 18]

21 Philosophia Sinica, p. 150.

22 Ibid., p. 163. 


\section{SINENSIS IMPERII LIBRI CLASSICI SEX}

From a sinological point of view, the translations of the "Six Classical Books" (Sinensis Imperii libri classici sex) ${ }^{23}$, that is the Confucian writings, the Great Learning 《大學》 [Adultorum Schola seu Doctrina, Ta Hio] ${ }^{24}$, Doctrine of the Mean 《中庸》[Immutabile Medium, Chum Yum] ${ }^{25}$, Analects 《論語》[Liber Sententiarum, Lun Yu $]^{26}$, Mencius 《孟子》 $[\text { Memcius, Mem Tsu }]^{27}$, Classic of Filial Piety 《孝經》 $[$ Filialis Observantia, Hiao Kim] ${ }^{28}$, and Small Learning 《小學》 [Parvulorum Schola seu Doctrina] $]^{29}$, is Noël's greatest contribution to Chinese studies. It was not based on the earlier Jesuit translations which culminated in the Confucius Sinarum philosophus, but a completely fresh work, and contained the first published translations in European languages of the Mencius, Filial Piety and Zhu Xi's primer, the Xiao xue.

The texts of the Four Books are preceded by Zhu Xi's prefaces from his annotated edition, the Si shu jizhu 四書集注 [Collected commentaries to the Four Books $]^{30}$, but Noël also used other sources. The translations are divided up in small, numbered sections like the Chinese original. When comments are given, often at the end of a section, they are usually accompanied by the name of the commentator. Many of the sentences are introduced by lengthy paraphrases and sometimes followed by brief, helpful explanations.

Unlike the translations of the Confucius Sinarum philosophus, there is no or very little Christian discourse interpolated in the text. Noël's work appears to be a serious attempt at a scholarly presentation of the ancient text, perhaps in deliberate contrast to the aims of the Jesuits who composed their Confucius Sina-

23 Sinensis Imperii libri classici sex: nimirum Adultorum Schola, Immutabile Medium, Liber Sententiarum, Memcius, Filialis Observantia, Parvulorum Schola. E Sinico idiomate in latinum traducti, a P. Francisco Noël Societatis Jesu Missionario. Pragæ, Typis Universitatis Carolo-Ferdinandeæ, in Collegio Soc. Jesu ad S. Clementem, per Joachimum Joannem Kamenicky p.t. Factorem, Anno 1711. [National Library in Prague, sign. D IV 34, 49 E 19]; the French translation: Les livres classiques de lempire de la Chine, recueillis par le Pere F. Noël, précédés d'Observations sur l'origine, la nature \& les effets de la philosophie morale \& politique dans cet empire. 7 vols. A Paris, Chez De Bure, Barrois aîné \& Barrois jeune, 1784-1786.

24 Sinensis Imperii liber primus classicus dictus Adultorum Schola, Sinicè Ta Hio, pp. 1-29.

25 Sinensis Imperii liber secundus classicus dictus Immutabile Medium, Sinicè Chum Yum, pp. 31-73.

26 Sinensis Imperii liber tertius classicus dictus Liber Sententiarum, Sinicè Lun Yu, pp. 75-198.

27 Sinensis Imperii liber quartus classicus dictus Memcius, Sinicè Mem Tsu, pp. 199-472.

28 Sinensis Imperii liber quintus classicus dictus Filialis Observantia, Sinicè Hiao Kim, pp. 473-484.

29 Sinensis Imperii liber sextus classicus dictus Parvulorum Doctrina seu Schola, Sinicè Siao Hio, pp. 485-608.

30 "Ad hunc libellum Sinicus Interpres $C h u$ hi sequens præmittit proœmium." - Sinensis Imperii liber primus classicus dictus Adultorum Schola, Sinicè Ta Hio, p. 1. rum philosophus half a century before. (Lundbæk 1991, p. 39) Although Noël translated six Confucian classics into Latin in 1711, his translations were banned by the authorities both in Rome and in Germany. Because of Jean-Baptiste Du Halde's (1674-1743; Chinese name: 杜赫德 Dù Hèdé) laudatory acknowledgment of Noël's work in the Description ${ }^{31}$, Noël exerted a great influence on German scholars such as Gottfried Wilhelm von Leibniz (1646-1716) and Christian Wolff (16791754) in the seventeenth and eighteenth century. ${ }^{32}$ Du Halde not only adopted Noël's translations of the Four Books, but also gave a summary and a commentary for each of the Confucian Five Classics as representing the primary body of the Chinese classical canon (livres canoniques du Premier ordre).

Sinensis Imperii libri classici sex is a comparatively free translation. Noël explains in the preface that it represents "not, so to say, what the Chinese wrote, but, I hope, what they really meant." 33 Noël is clearly using the standard Zhu Xi edition, since he includes in each case Zhu Xi's preface. But his interpretation is European and scholastic, in a mode that has many precedents in the China Mission. (Rule 2003, p. 158).

A good example is the opening line of his translation of the Zhong yong 中庸 ("Doctrine of the Mean"). The original literally goes something like this: "the mandate of Heaven is called nature; to follow nature is called the way; to cultivate the way is called teaching." ${ }^{34}$ Ninety years before, when called upon to comment upon this passage in a scholarly academy in Fuzhou 福州, Giulio Aleni, SJ (or Alenio, 1582-1649; Chinese name: 艾儒略 Ài Rúlüe), had interpreted it as follows: “The Law of Heaven is called Nature. To follow its direction is called the way, or natural law. To particularize and order this natural law, is called positive law." ${ }^{35}$ Noël's interpretation is far less tendentious, but still includes a distinctly scholastic flavour: "the law of Heaven is nature itself; the tendency of this nature is the way of acting correctly; the direction of this life is a right discipline of life, or the right precepts for living." ${ }^{36}$

31 Description géographique, historique, chronologique, politique, et physique de l'empire de la Chine et de la Tartarie chinoise, enrichie des cartes générales et particulieres de ces pays, de la carte générale et des cartes particulieres du Thibet, \& de la Corée; \& ornée d'un grand nombre de figures \& de vignettes gravées en tailledouce. A La Haye, Chez Henri Scheurleer, 1736, 4 vols. in folio.

32 Donald F. Lach, "The Sinophilism of Christian Wolff (16791754),", Journal of the History of Ideas, 14 (1953), 561-574. See also his "Leibnitz and China," Journal of the History of Ideas, 6 (1945), 436-455.

33 "non tantùm ut discas, quæ Sinæ scripserunt, sed \& ut agas, quæ rectè senserunt" - Sinensis Imperii libri classici sex, "Profatio ad lectorem", p. 1.

\section{$34 「$ 天命之謂性 ; 率性之謂道 ; 修道之謂教。」(中庸 I.1)}

35 Bartoli, Daniello, SJ, Historia della Compagnia di Giesu del R. P. Daniello Bartoli della medesima Compagnia: la Cina, terza parte dell'Asia. Roma, de Lazzeri, 1663, p. 812.

36 "Cæli lex est ipsa natura; hujus naturæ ductus est recta agendi via; hujus viæ directio est recta vitæ disciplina, seu recta vivendi præcepta." - Sinensis Imperii liber secundus classicus dictus Immutabile Medium, Sinicè Chum Yum, p. 41. 


\section{HISTORICA NOTITIA RITUUM}

The last of the trilogy published in 1711 in Prague is the Historica notitia rituum ac ceremoniarum Sinicarum..$^{37}$ The polemical contents of this work on the Rites issue give the lie to the claim that Noël was a turncoat, and its combative tone throws doubt on the idea that he was lying low in Prague to avoid censure. (Rule 2003, p. 159) The Historica notitia rituum covers much the same ground as the second treatise of the Philosophia Sinica ${ }^{38}$ but in somewhat greater detail, and with liberal citations from Chinese texts. The subtitle insists that it is "drawn from the very books of Chinese authors" 39 but goes on to add "by special license of His Holiness Pope Clement XI. and by the permission of the superiors" 40 . This may have been what caused problems for the book, since Noël was referring to the Pope's permission of mid 1704 to publish the material brought from China.

Henri Cordier (1849-1925) quotes a manuscript note of Guillaume Pauthier (1801-1873): "It appears that this book was suppressed on its appearance by superior order, or withdrawn from circulation by its author, a short time after its publication." ${ }^{41}$ There is no evidence for this, and certainly it was never formally banned by Rome, but perhaps Noël's superiors restricted its circulation. The arguments of the Historica notitia rituum are again standard, but backed up by liberal citation. Noël also displays considerable knowledge of the historical development of ancestor rituals, pointing, for example, to the late introduction of the wooden tablets to replace the form of ancestor ritual described in the Shi jing 《詩經》 where a small boy stands in for the deceased. ${ }^{42}$

\section{CONCLUSION}

After 1711 we almost lose sight of Noël until his death on 17 September 1729 in Lille (France). On 10 June 1715 Noël applies for a new authorization to return to China. This was three month after Clement XI had issued Papal bull Ex illa

37 Historica notitia Rituum ac Ceremoniarum Sinicarum In colendis Parentibus ac Benefactoribus Defunctis, Ex ipsis Sinensium Authorum libris desumpta. A P. Francisco Noël, Societatis Jesu Missionario. Pragæ, typis Univers. Carolo-Ferdinand. in Collegio Soc. Jesu ad S. Clementem, per Joachimum Joannem Kamenicky Factorem, Anno 1711. [National Library in Prague, sign. B IV 262]

38 Philosophia Sinica, Tractatus II. "De Ceremoniis Sinarum erga Denunctos".

39 "Ex ipsis Sinensium Authorum libris desumpta".

40 "De speciali Licentia SS.D.N.D. Clementis Papæ XI. et Superiorum Permissu".

41 Bibliotheca sinica. Dictionnaire bibliographique des ouvrages relatifs à l'Empire chinois. Tome 2, par Henri Cordier. Paris, Ernest Leroux, éditeur 1885, p. 915.

42 Historica notitia Rituum. CAPUT V. "De Parentali signo seu lignea Tabella, sinicè Mo chu, quam erigunt Sinæ ad colendos Defunctos”, p. 44; cf. Shi jing II. 6. (209) 楚茨. die, which officially condemned the Chinese rites. In the end, Noël has returned to Lille (we don't know exactly the reasons - age, illness, or other circumstances) where he continued his research and writing in Sinology. His works demonstrate a thorough knowledge of the literature and Chinese thought. Whereas the translations of the Confucian classics made by Fr. Intorcetta and other Jesuits which culminated in Confucius Sinarum philosophus (1687) were familiar to Voltaire (François-Marie Arouet, 1694-1778) and other French philosophers, Du Halde helped to disseminate the less well-known translations published by François Noël in 1711. Du Halde states that he had drawn his understanding of the Four Books from Fr. Noël's translations and recommends them to readers interested in improving their understanding. ${ }^{43}$ (Mungello 1991, p. 107) Although Confucius Sinarum philosophus and Noël's Sinensis imperii libri classici sex differ in many respects, they both emerged from the same long-term Jesuit translation project which is traceable to Ruggieri and Ricci's pioneering efforts in the closing years of the sixteenth century. Noël's translations represent a culmination of that project in the sense that they are more refined versions of the original translations. Furthermore, whereas Confucius Sinarum philosophus omitted Mencius, Noël included all of the Four Books.

François Noël thus ranks among the most important cultural intermediaries between China and Europe in the early 18th century. His translations have sustainably influenced the Enlightenment in Europe because they dropped a theological interpretation and thus displayed an image of a philosophy, which had given continuity and social stability of an ancient culture without God and the Church. ${ }^{44}$

Noël's work is full of protracted paraphrases of Medieval Latin, and this can be conceived as a product of cultural translation under the principle of domestication in early modern Europe. It is known that Noël attracted widespread criticism for his conscious effort to intermingle the text and the com-

43 "Ceux qui voudront avoir une connoissance plus parfaite de ces ouvrages, la trouveront dans la traduction latine qu'en a fait le P. Noël, l'un des plus anciens Missionnaires de la Chine, qui fut imprimé à Prague en l'année 1711. C'est de sa tradudion, que j’ai tiré les connoissances que je donne des livres suivans." - Jean-Baptiste Du Halde, Description géographique, historique, chronologique, politique, et physique de l'empire de la Chine et de la Tartarie chinoise, enrichie des cartes générales et particulieres de ces pays, de la carte générale et des cartes particulieres du Thibet, \& de la Corée; \& ornée d'un grand nombre de figures \& de vignettes gravées en taille-douce. Par le P. J. B. Du Halde, de la Compagnie de Jésus. Vol. II. A La Haye, Chez Henri Scheurleer M. DCC. XXXVI. (1736), p. 389.

44 "Aussi peut-on assurer que jamais les livres de Confucius et de ses disciples nont été aussi bien entendus, ni aussi complètement expliqués qu'ils le sont dans l'ouvrage du P. Noël." [We can ensure as well, that he books of Confucius and his disciples were not as well understood or as completely explained as they are in the work of Father Noël]. - Biographie universelle, ancienne et moderne, ou Histoire, par ordre alphabétique, de la vie publique et privée de tous les hommes qui se sont fait remarquer par leur écrits, leurs actions, leurs talents, leurs vertus ou leurs crimes. Paris, Chez L. G. Michaud, 1822, tome 31 , p. 336. 
mentaries. However, as the Jesuits were evidently not able to translate separately the Four Books and the commentaries during the seventeenth century, it was necessary for them to add the commentaries to the text in order to make the translation more intelligible to the literati in the Western world at that time. For precisely the same reason, Noël's paraphrastic renderings did not only come from the original Chinese text and the commentaries, but also from his own elaboration. (Wong 2013, p. 171)

\section{REFERENCES}

Chatterjee, Kumkum - Hawes, Clement, eds. (2008): Europe Observed: Multiple Gazes in Early Modern Encounters. Lewisburg, PA, Associated University Presse.

Chen Shouyi (陳受頣) (1970): 中歐文化交流史事論叢 [Discourses on the History of China - European Cultural Communication]. Taipei, Commercial Press 臺灣商務印書館.

D’Arelli, Francesco (1998): "Matteo Ricci S.I. e la traduzione latina dei "Quattro libri” (Sishu). Dalla tradizione storiografica alle nuove ricerche, in Le Marche e l'Oriente, una tradizione ininterrotta da Matteo Ricci a Giuseppe Tucci," in: Atti del convegno internazionale, Macerata 23-26 ottobre 1996, a cura di F. D’Arelli. Roma: Istituto Italiano per l'Africa e l'Oriente, $163-175$.

Dai Wei-Yang (戴維揚) (1981): “Confucian and Christian Canons 論儒家經 典西譯與基督教聖經中譯”, 《教學與研究》, 3 (05), 247-278.

Lee, Thomas H. C. (李弘祺), ed. (1991): China and Europe: images and influences in sixteenth to eighteenth centuries. Hong Kong, The Chinese University Press.

Lundbæk, Knud (1991): “The First European Translations of Chinese Historical and Philosophical Works," 29-44.
Meynard, Thierry (梅謙立) (2010): “《論語》在西方的第一個版本 (1687) / The First Edition of the Analects of Confucius in the West (1687)," 神州 交流 / Chinese Cross Currents, Vol. 7, No. 2, 98-111.

Mungello, David E. (1991): "Confucianism in the Enlightenment: Antagonism and Collaboration between the Jesuits and the Philosophes," in Lee, 99-128.

Mungello, David E. (1989): Curious Land: Jesuit Accommodation and the Origins of Sinology. Honolulu, University of Hawaii Press.

Mungello, David E. (1983): “The First Complete Translation of the Confucian Four Books in the West," in International Symposium on Chinese-Western Cultural Interchange in Commemoration of the 400th Anniversary of the Arrival of Matteo Ricci, S.J. in China / 紀念利瑪賔來華四百週年中西 文化交流國際學術會議論文集. Taipei, Fu Jen University Press 輔仁大 學出版社, 515-541.

Pinch, William R. (2011): "The Corpse and Cult of St. Francis Xavier, 15521623," in Mathew N. Schmalz and Peter Gottschalk ed. Engaging South Asian Religions: Boundaries, Appropriations, and Resistances. New York, State University of New York Press.

Po-Chia Hsia, Ronnie (2008): "The Question of Who: Chinese in Europe," in Chatterjee, 83-102.

Possevino, Antonio (1593): Antonii Possevini Societatis Iesv Bibliotheca selecto qua agitur de ratione stvdiorum in historia, in disciplinis, in salute omnium procuranda. T. I. Romæ: Ex Typographia Apostolica Vaticana, M. D. XCIII.

Rule, Paul (1973): “Confucius or K’ung-t’zu,” Diss. Australia.

Rule, Paul (2003): "François Noël, SJ, and the Chinese Rites controversy," in Walle,135-166.

Walle, W. F. Vande - Noël Golvers, eds. (2003): The History of the Relations Between the Low Countries and China in the Qing Era (1644-1911). Leuven/Louvain, Universitaire Pers Leuven / Leuven University Press / Presses Universitaires de Louvain.

Wong Ching Him, Felix (黃正謙) (2013): 論耶穌會士衛方濟的拉丁文 《孟子》翻譯 [On the Latin Translation of Mencius of François Noël, SJ], Journal of Chinese Studies 《中國文化研究所學報》, 57, 133-172. 